GEOGRAFICKÝ ČASOPIS / GEOGRAPHICAL JOURNAL 71 (2019) 2, 141-159

DOI: https://doi.org/10.31577/geogrcas.2019.71.2.08

\title{
IMPLEMENTÁCIA ALTERNATÍVNYCH HODNOTENÍ EKOLOGICKEJ STABILITY KRAJINY: PRÍPADOVÁ ŠTÚDIA ENVIRONMENTÁLNE ZAŤAŽENÉHO ÚZEMIA RUDŇANY
}

\author{
Matej Hruška*, Vladimír Falt’an*, Monika Ivanová** \\ * Univerzita Komenského v Bratislave, Prírodovedecká fakulta, Katedra fyzickej geografie a geoekológie, \\ Mlynská dolina,84215 Bratislava, hruska35@uniba.sk, vladimir.faltan@uniba.sk \\ ** Prešovská univerzita v Prešove, Fakulta humanitných a prírodných vied, Katedra geografie a aplikovanej \\ geoinformatiky, Ul. 17 novembra 1, 08116 Prešov, monika.ivanova@unipo.sk
}

\begin{abstract}
Implementation of alternative assessments of ecological stability of a landscape: a case study of the environmentally affected area of Rudňany

Many indicators trying to assess the state of such a highly complex system have been created so far. In this paper, we present the use and usefulness of surrogate measures of the ecological stability assessment in an environmentally-affected area. The cadastral territory of the municipality Rudňany, located in the Slovenské rudohorie Mts. (Eastern Slovakia), was used because of long term impact of mining and processing minerals. The large-scale analysis of the secondary landscape structure was based on aerial photography from 2013, field research and delineated land cover classes on the 5th hierarchical level. The modified Indicator of Ecological Stability - IELS was calculated for the whole study area and also separately for the grid areas of the size $100 \times 100 \mathrm{~m}$. Used measures include landscape diversity, the weighting score of hemeroby and the character of ecological corridors and barriers. Identification and inventorying of land cover classes at a scale of 1:10 000 with respect to the minimum mapping area of 0,1 ha resulted in a decrease in the IELS. It was verified by a bottom-up aproach and a layer based on nomenclature for Phare countries. The lower value of the IELS is related to the possibility of more detailed mapping of the real state of the landscape structure and its importance for ecological stability of landscape. Used grid method revealed high IELS in squares representing transitional zones between adjacent ecosystems - ecotones.
\end{abstract}

Key words: ecological stability, CORINE Land Cover, landscape diversity, hemeroby, assessment, environmental loaded area, municipality of Rudňany

\section{ÚVOD}

Ekologická stabilita (ES) je široko chápaný pojem, ktorý sa týka rôznych prírodných komponentov krajiny ovplyvňovaných antropogénnymi aktivitami a ich priamymi a nepriamymi dosahmi (napr. hluk, znečistenie, rozširovanie zastavaného územia a pod.). Problematike ekologickej stability sa venovalo vel'ké množstvo zahraničných autorov, spomenieme napr. Verstaete et al. (2007), Dalleau et al. (2010), Peano a Cassatella (2011), Sowińska-Świerkosz a Soszyński (2014), Pierson et al. (2015) a Lin et al. (2016). Táto tematika zaujala aj viacero domácich vedeckých pracovníkov, napr. Izakovičová (1999), Tremboš (2002), Reháčková et al. (2008), Gajdoš et al. (2012), Ivanová et al. (2013b) a Oláhová et al. (2013). Ekologickú stabilitu môžeme chápat' ako schopnost' ekologického systému pretrvávat' aj počas pôsobenia rušivého vplyvu a reprodukovat' svoje podstatné charakteristiky v podmienkach vonkajšieho narušovania (Míchal 1994).

Jedným z najefektívnejších aktuálne používaných nástrojov na posúdenie stavu takéhoto vysoko komplexného systému je aplikácia rôznych indikátorov. V rámci geografického a krajinnoekologického výskumu sa stabilita krajiny vyjadruje koeficientom ekologickej stability (KES). Najčastejšie sa v našich podmienkach uplatňu- 
jú dva prístupy stanovenia KES (pozri napr. Reháčková a Pauditšová 2007, Boltižiar a Oláh 2009 a Pauditšová 2010): 1. KES ako podiel relatívne stabilných plôch ku relatívne nestabilným plochám (Míchal 1994, Stred'anský a Šimonides 1995, Žigrai 2001 a Muchová a Tárniková 2018). Výhodou spomínaného prístupu je vel'mi jednoduchá metodika, vzorce možno účelovo upravovat' a doplňat' o skupiny nových prvkov. Nevýhodou je nezohl'adňovanie miery ekologickej významnosti jednotlivých krajinných prvkov. 2. KES stanovený na základe plošného zastúpenia stabilných a nestabilných prvkov krajiny s prihliadnutím na mieru ich ekologickej významnosti, ktorá je vyjadrená váhovým koeficientom. (Löw 1984 a Miklós 1986). S korigovaným Miklósovým matematickým vzt'ahom prišli Ot’ahel' et al. (2004), kde sa okrem tried krajinnej pokrývky (TKP) zamerali na prírodnú krajinu a socioekonomické funkcie krajiny. V prípade vzorca Reháčkovej a Pauditšovej (2007), ktorý používa váhový koeficient, je výhodou zohl'adnenie stavu aktuálnej vegetácie a stupňa hemeróbie. Nevýhodou je zohl'adňovanie len plošného podielu jednotlivých prvkov druhotnej krajinnej štruktúry (DKŠ) z celkovej rozlohy územia bez kvantifikovania kompozície krajinnej štruktúry odzrkadl'ujúcej variabilitu a abundanciu rôznych typov TKP.

Špecifickým prístupom pri vyhodnocovaní stability krajiny sú krajinno-ekologické indexy, resp. algoritmy kvantifikujúce vlastnosti priestorovej štruktúry plôšok (polygónov) TKP (pozri napr. Ivanová et al. 2013a). Počet a priestorové usporiadanie plôšok úzko súvisia so šírením disturbancií (Forman a Godron 1993), čo sa odráža na celkovej stabilite krajiny. Zo širokého spektra vlastností, ktoré možno vyhodnotit', sme sa zamerali na krajinnú diverzitu (Kopecká 2011, Ot'ahel' 2011 a Ramezani 2012) a ekologickú významnost' ekotonov lesnej vegetácie (Gajdoš et al. 2012).

Hlavným ciel'om predkladaného článku je syntéza rôznych hodnotení ekologickej stability kultúrnej krajiny s využitím legendy na identifikáciu a zaznamenávanie TKP v mierke 1:10 000, váženého skóre hemeróbie a indikátora ekologickej stability krajiny. Navrhovaný postup je realizovaný na príkladovej štúdií katastrálneho územia Rudňany v regióne s vysokým stupňom environmentálnej zát’aže.

V príspevku sa venujeme verifikácii nasledovných vedeckých hypotéz:

- Použitie detailnejšieho členenia DKŠ aplikáciou modifikovanej metódy CORINE Land Cover a legendy krajinnej pokrývky na 5. hierarchickej úrovni (Ot'ahel' et al. 2017) pomôže lepšie kvantifikovat' výstupy hodnotenia a prinesie detailnejší obraz o ekologickej stabilite krajiny;

- Vyššiu ekologickú stabilitu v kultúrnej krajine nachádzame vo štvorcoch s výskytom dvoch alebo viacerých TKP predstavujúcich prechodné zóny medzi susediacimi ekosystémami, ktoré sú charakteristické potenciálne zvýšenou diverzitou.

\section{SYNTÉZA HODNOTENÍ EKOLOGICKEJ STABLITY}

Pri výbere najvhodnejšieho postupu odzrkadl'ujúceho ekologickú stabilitu krajinu sme vychádzali z prehl'adu literatúry, aby sme sa čo najviac priblíži k aktuálne aplikovaným metódam. Prvým vybraným bol Shannonov index diverzity SHDI (Shannon 1948). Použitie SHDI bolo založené na predpoklade, že zaznamenávanie DKŠ pomocou metódy dial'kového prieskumu Zeme je dobrým prediktorom vzoriek (patternov) miestnej biodiverzity (Ewers et al. 2005), ktoré ovplyvňujú odolnost' a stabilitu ekosystémov (Aragon et al. 2011). Meranie diverzity krajiny úzko súvisí s mierkou a obsahom identifikovaných objektov, ktoré určujú kvalitu 
(detailnost') priestorového a obsahového poznania (homogénnost') reálneho stavu krajinnej štruktúry. Získané informácie o krajinnej diverzite sú nielen významným indikátorom stavu krajiny, ale aj dôležitým čiastkovým výstupom na získavanie d'alších charakteristík, ako je napr. heterogenita krajiny (Ivanová et al. 2011) alebo ekologická stabilita (Hanušin a Stefunková 2015). SHDI sa však zameriava len na početnost' TKP a vyrovnanost' ich vel'kosti, pričom neberie do úvahy ich ekologickú významnost', čo na druhej strane zohl'adňuje matematický vzt'ah publikovaný v práci Miklósa (1986).

TKP môžeme vnímat' ako biotopy alebo komplexy biotopov (Tallis et al. 2011) s rôznym stupňom hemeróbie, ktorá predstavuje mieru vplyvu l'udských aktivít na vegetáciu alebo na celkový ekosystém. Ked’že príkladová štúdia bola realizovaná na území s dlhodobým intenzívnym vplyvom človeka, rozhodli sme sa využit' hemeróbiu na vyjadrenie ekologickej významnosti krajinnej pokrývky. Pri prirad'ovaní váženého skóre hemeróbie TKP sme sa opierali o práce realizované v podmienkach Strednej Európy (Jurko 1990, Wittig 1998, Rüdisser et al. 2012, Walz a Stein 2014, Sowińska-Świerkos 2017 a Druga a Minár 2018) a vychádzali z mapovania aktuálnej vegetácie a biotopov (Leskovjanská et al. 2013).

Pre korektné stanovenie ekologickej stability územia je žiaduce, aby sa do úvahy brali aj bariéry vyskytujúce sa v krajine. Dôležitými bariérovými prvkami podiel'ajúcimi sa na fragmentácii krajinných systémov sú komunikácie. Problematikou dopravnej infraštruktúry a jej negatívnymi vplyvmi na krajinu sa zaoberali napr. Jaeger a Fahrig (2004) a Karlson et al. (2014). Významnou je práca autorov van der Ree et al. (2011), ktorá dokumentuje účinok ciest a dopravy na populácie rastlinných a živočíšnych spoločenstiev. Tento negatívny vzt’ah medzi dopravnými líniami a ekologickou hodnotou biotopov závisí od ich lokalizácie v krajine, okolitej krajinnej pokrývky/využitia krajiny, hustoty cestnej siete (Forman a Alexander 1998) a typu cesty (Su et al. 2014).

\section{MATERIÁL A METÓDY}

Ako podklad k vizuálnej interpretácii DKŠ sme vybrali farebnú leteckú ortofotosnímku z roku 2013 s rozlíšením rastra $0,5 \mathrm{~m}$ verifikovanú terénnym výskumom, ktorý sme realizovali v roku 2016. Ortofotosnímka bola interpretovaná pomocou metodiky CORINE Land Cover (CLC) a legendy pre identifikovanie a zaznamenávanie TKP v mierke 1:10 000 (Ot’ahel' et al. 2017). Prostredníctvom vektorizácie rastrového mapového podkladu (ortofotomapy) sme vytvorili mapu krajinnej pokrývky pri rešpektovaní minimálneho mapovaného areálu 0,1 ha $\mathrm{v}$ prostredí ArcGis 10.1 (C) ESRI). Len v prípade urbanizovaných areálov sme vzhl'adom na ciele práce identifikovali detailnejšie aj samostatné budovy a vegetáciu v ich okolí, ktoré toto kritérium nesplńnali. Zmyslom uvedeného prístupu bolo zachytit’ čo najväčšie množstvo biotickej zložky a stanovit' jej ekologickú významnost' (Ot'ahel' et al. 2004).

Na základe uvedených spomínaných skutočností sme pre komplexnost' charakteristík kombinovali SHDI, Miklósov vzorec (1986) a vážené skóre hemeróbie $-h_{i}$ (tab. 1.). TKP boli $\mathrm{k}$ stupňom hemeróbie a váženému skóre priradené na základe podrobného popisu stanovištných podmienok a vegetácie. $\mathrm{V}$ prípade, ak popis nebol dostatočne detailný, trieda krajinnej pokrývky nebola zapísaná na 5. hierarchickej úrovni, ale na vyššej úrovni. Umožnil nám to systémový prístup analyzovania krajinnej pokrývky (Ot’ahel' et al. 2004) a mapovanie vo vel'kých mierkach prístupom ,zhora - nadol“" (Kleeschulte et al. 2016). 
GEOGRAFICKÝ ČASOPIS / GEOGRAPHICAL JOURNAL 71 (2019) 2, 141-159

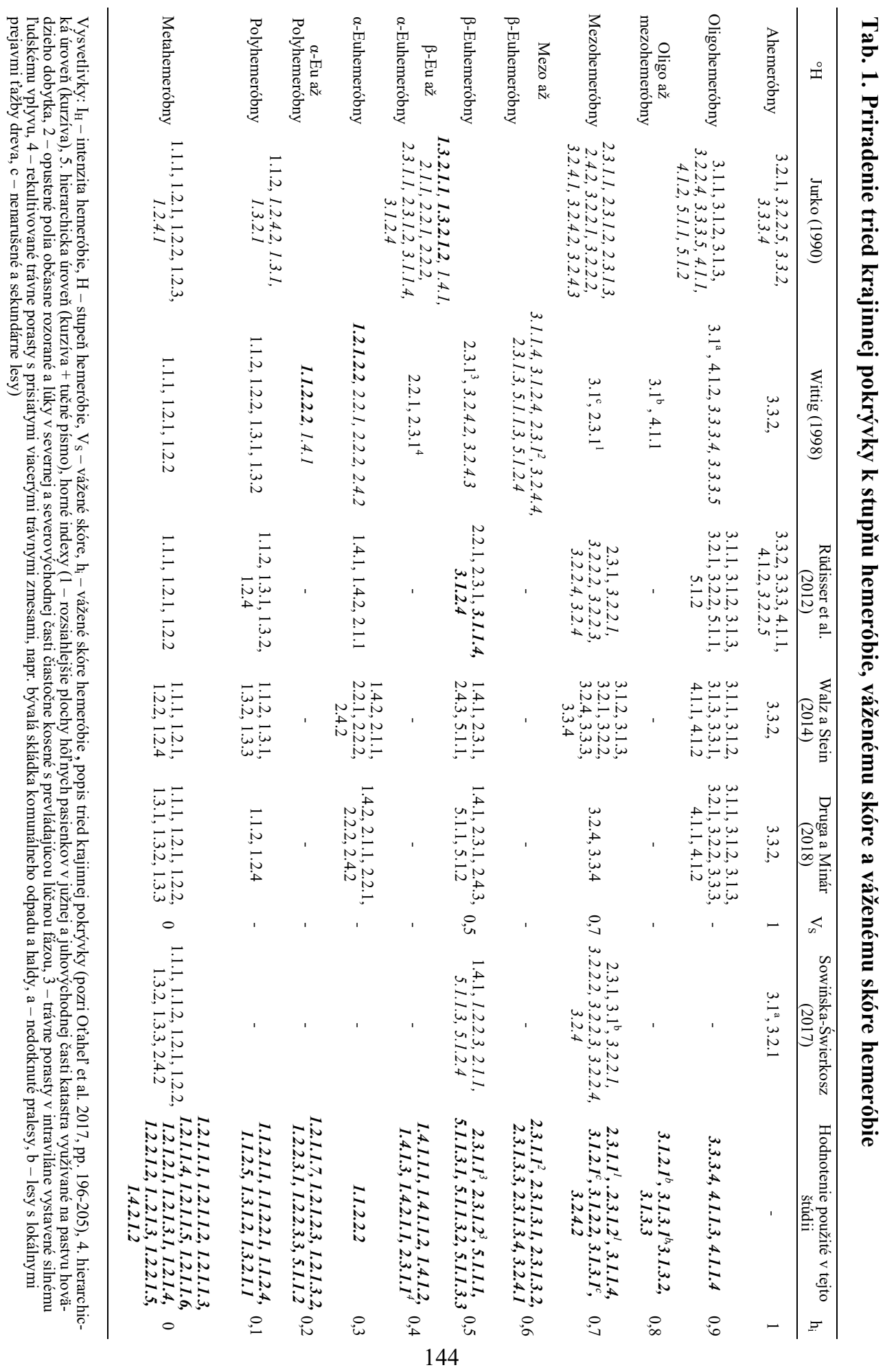


Na základe spomínaných skutočností sme definovali nasledujúci index ekologickej stability (IES):

$$
I E S=\left(-\sum_{i=1}^{s} p_{i}^{1} * \ln p_{i}\right) *\left(\frac{\sum_{i=1}^{s} p_{i}^{2} * h_{i}}{p}\right),
$$

kde $p_{i}{ }^{1}$ predstavuje podiel rozlohy i-tej triedy krajinnej pokrývky z celkovej rozlohy analyzovanej priestorovej jednotky, $s$ je celkový počet tried krajinnej pokrývky $\mathrm{v}$ analyzovanej priestorovej jednotke, $p_{i}{ }^{2}$ je rozloha i-tej triedy krajinnej pokrývky v analyzovanej priestorovej jednotke, $h_{i}$ je vážene skóre hemeróbie i-tej triedy krajinnej pokrývky a $p$ je celková rozloha analyzovanej priestorovej jednotky. Výsledný index bol upravený podl'a práce Ramezani (2012) do podoby Shannonovho indexu vyrovnanosti, ktorý sme doplnili o vážené skóre hemeróbie $\left(\mathrm{SHEI}^{h i}\right)$ :

$$
S H E I^{h i}=\frac{-\sum_{i=1}^{s} p_{i} * \ln p_{i} * h_{i}}{\ln s}=\frac{S H D I * h_{i}}{\ln s},
$$

kde $p_{i}$ predstavuje podiel rozlohy i-tej triedy krajinnej pokrývky z celkovej rozlohy analyzovanej priestorovej jednotky, $h_{i}$ je vážene skóre hemeróbie i-tej triedy krajinnej pokrývky, $s$ je celkový počet tried krajinnej pokrývky. $S H E I^{h i}$ nadobúda hodnotu 0 - ak je celá krajina tvorená TKP $\mathrm{s}$ váženým skóre hemeróbie 0 (devastovaný) a hodnotu 1 - ak je celá krajiny tvorená TKP s vysokým váženým skóre hemeróbie (prírodné a blízke prírode). Takýto prístup sa zakladá na hypotéze, že čím menej je biotop pozmenený, tým je vhodnejší pre rôzne druhy (Terrado et al. 2016), a preto je vyššia jeho ekologická významnost'. V rámci prezentovaného indexu boli použité dodatočné premenné, ktoré vstupujú do celkového výpočtu. Patria sem riečne údolia s brehovými porastmi (ekologickými koridormi - EK), ktorých význam dobre zhrnuli Forman a Godron (1993, pp. 150 - 158). Mackovčin (2000) však poukazuje na skutočnost', že nie každý vodný tok má rovnakú environmentálnu hodnotu a je súčast’ou ekologickej siete. Líniová forma vodných tokov svedčí o krajine so silným vplyvom človeka, preto štrukturálny charakter možno považovat' za dôležitý pri učení vplyvu na ekológiu krajiny (Sowińska-Świerkosz a Soszyński 2014). Pri vyhodnocovaní vodných tokov boli do úvahy brané len tie, ktoré si zachovávali prirodzený tvar a neprechádzali urbanizovanými (technizovanými) a pol’nohospodárskymi areálmi. Identifikované boli pomocou topografických máp s reálnou situáciou z rokov 1980 a 1991 v mierke 1:10 000. Vytvorená bola nová líniová vrstva vodných tokov, ktoré splńnali dané kritéria a ich dľžka bola vypočítaná pomocou funkcie v GIS programe. Dalšou premennou je dopravná infraštruktúra v podobe ciest, ktoré vystupujú ako ekologické bariéry (EB), a tak znižujú ekologickú stabilitu. Za bariéry sme považovali len tú čast' triedy 1.2.2.1.2 cesty so spevneným povrchom (cesta III. triedy č. 3244), ktorá prechádzala cez areály tráv, lesné a poloprírodné areály. Na základe spomínaných kritérií sme vytvorili novú dátovú vrstvu, ktorou sme prekryli vrstvu krajinnej pokrývky a nástrojom „Intersect“ s nastavením výstupu líniovej vrstvy sme získali línie bariér. Dížka každého takto vzniknutého úseku bariéry bola vypočítaná pomocou nástroja „Calculate Geometry“ a následné spriemerovaná.

Finálna podoba indikátora pre výpočet ekologickej kvality (stability) krajiny, ktorý je založený, na krajinnej pokrývke a určení úrovne jej antropogénnej premeny (Sowińska-Świerkosz 2017): 


$$
I E S K=\left(\frac{-\sum_{i=1}^{s} p_{i} * \ln p_{i} * h_{i}}{\ln s}\right)+\sqrt{\frac{R_{d}}{p}-\sqrt{\frac{C_{d}}{p}=S H E I^{h i}+E K-E B}},
$$

kde $p_{i}$ predstavuje podiel rozlohy i-tej triedy krajinnej pokrývky k celkovej rozlohe analyzovanej priestorovej jednotky, $h_{i}$ je vážené skóre hemeróbie i-tej triedy krajinnej pokrývky, $s$ je celkový počet tried krajinnej pokrývky, $R_{d}$ je dížka prirodzeného stavu vodného toku (nadobúda hodnotu 1 - ak hustota netransformovaných vodných tokov je $1 \mathrm{~km} / \mathrm{ha}$ ), $C_{d}$ je dížka ekologických bariér (nadobúda hodnotu 0 ak sa v krajine nevyskytujú žiadne ekologické bariéry, 1 - ak je hustota ekologických bariér $1 \mathrm{~km} / \mathrm{ha}$ ) a $p$ je celková rozloha analyzovanej priestorovej jednotky.

IESK nadobúda hodnoty medzi 0 a 2 . Vypočítaná hodnota sa zvyšuje s nárastom úrovne ekologickej stability krajiny. Indikátor nadobúda hodnotu 2, ak je celá krajina tvorená TKP s vysokým váženým skóre hemeróbie (prírodné a blízke prírode), ktoré sú perfektne priestorovo rozmiestnené, hustota netransformovaných vodných tokov je $1 \mathrm{~km} / \mathrm{ha}$ a v krajine nie sú žiadne ekologické bariéry, prípadne je celá krajina tvorená lesnými a poloprírodnými areálmi a hustota netransformovaných vodných tokov je väčšia ako $1 \mathrm{~km} / \mathrm{ha}$. Hodnotu 0 nadobúda, ak je celá krajina tvorená TKP, ktoré sú zaradené do stupňa hemeróbie - metahemeróbny. Môže nadobúdat' aj mínusové hodnoty, ak vplyv ekologických bariér v analyzovanej priestorovej jednotke je vyšší ako súčet $S H E I^{h i}$ s $E K$.

Všetky vytvorené polygóny s rovnakým kódom príslušnej TKP a váženým skóre hemeróbie v atribútovej tabul'ke boli pomocou nástroja „Merge“ spojené do novej spoločnej dátovej vrstvy pre každú TKP. Rozloha novovytvorených dátových vrstiev a celého skúmaného územia bola vypočítaná použitím nástroja „Calculate Geometry“. Výpočet IESK sme realizovali v prostredí programu ArcGis 10.1 (C) ESRI) pre celé skúmané územie a pravidelnú štvorcovú siet' s reálnou vel'kost'ou štvorca 1 ha $(100 \times 100 \mathrm{~m})$. Vel'kost' štvorca bola stanovená s ohl'adom na zaznamenávanie TKP v mierke 1:10 000 a minimálneho mapovaného areálu 0,1 ha. Podobnú vel'kost' štvorca využila Turner (1987) pri porovnávaní priestorových modelov zmien krajiny, Gascon et al. (1999) pri skúmaní reakcie živočíšnych druhov na fragmentáciu krajiny a Boltižiar (2010) pri sledovaní heterogenity vysokohorskej krajiny. Hlavným dôvodom použitia štvorcovej mriežky bola snaha o získanie reprezentatívnych výsledkov s jednotnou priestorovou detailnost'ou a obsahovou podrobnost'ou.

\section{SKÚMANÉ ÚZEMIE}

Katastrálne územie Rudňany s rozlohou 1343 ha sa nachádza na východnom Slovensku v okrese Spišská Nová Ves. Podl'a geomorfologického členenia Slovenska (Mazúr a Lukniš 1896) je zaradené do geomorfologickej oblasti Slovenského rudohoria, celku Volovské vrchy a podcelku Hnilecké vrchy. Severná čast' územia zasahuje do geomorfologickej časti Galmus. Nadmorská výška sa pohybuje od 475 do $900 \mathrm{~m} \mathrm{n}$. m. Na geologickej stavbe územia sa podiel'a tektonická jednotka gemerika a tektonická jednotka silicikum; paleogén je zastúpený podtatranskou skupinou a z nečleneného kvartéru zaberajú najväčšiu čast' územia deluviálne sedimenty (Mello et al. 2000).

Dominantnými geomorfologickými formami sú erózno-denudačné svahy, široké rázsochovité chrbty a zvyšky kedysi rozsiahlejšej krasovej planiny v severnej 
časti katastra (Čech a Krokusová 2013). Z antropogénnych foriem reliéfu sa v území nachádzajú haldy, pingy, prepadliská a kameňolom. Podl’a klimatickej klasifikácie Slovenska (Lapin et al. 2002) sa územie začleňuje do chladnej klimatickej oblasti a okrsku $\mathrm{C}$, mierne chladný, vel'mi vlhký s priemernou júlovou teplotou $\geq 12^{\circ} \mathrm{C}$ a $<16^{\circ} \mathrm{C}$. Hlavným vodným tokom je Rudniansky potok s plochou povodia $23,6 \mathrm{~km}^{2}$. Pôvodná prirodzená vegetácia bola vplyvom t’ažby a spracovania nerastných surovín počas dlhého obdobia exploatovaná.

Obec Rudňany mala od svojho vzniku trvalú spojitost' s rudným baníctvom. Najväčší rozvoj zaznamenali Rudňany v roku 1946. Miestne bane boli znárodnené, bol vybudovaný Nový priemyselný závod (NPZ), mlynica a ortut'ovňa. V súčasnosti sú všetky povrchové prevádzky zlikvidované s výnimkou úpravne a mlynice, ktoré spoločnost' SABAR, s. r. o., d'alej využíva pri spracovávaní síranu bárnatého. Za takmer 700 rokov sa v Rudňanoch vyt'ažilo cca 42 mil. ton rúd. Na základe environmentálnej regionalizácie Slovenska publikovanej v Správe o stave životného prostredia (MŽP SR 2005) patrí skúmané územie do Rudniansko-gelnickej zat’aženej oblasti. Za zdroje rizikových zložiek sú považované haldy vyt'aženej rúbaniny (rudné, hlušinové), skládky odpadu po úprave rudy mletím a pražením, skládka flotačného kalu a pôda kontaminovaná imisiami z tepelnej úpravy rúd. Pôdy kontaminované imisiami sa nachádzajú od areálu NPZ smerom na juh a extrémne zasiahnutý je karbonátový masív Stožky. Znečistenie sa šíri infiiltráciou zrážkovej vody, povrchovým a podzemným odtokom a koncentruje sa do Rudnianskeho potoka. Za najvýznamnejší kontaminant oblasti možno považovat' antimón, bárium a ortut' (Pramuk a Matiová 2015 a Liščák et al. 2016). Z novších prác sa kontamináciou pôdy a vegetácie v ned'alekej Jelšavsko-lubeníckej zat'aženej oblasti zaoberali Fazekaš et al. (2018).

\section{VÝSLEDKY}

Vytvorená mapa krajinnej pokrývky (obr. 1.) z roku 2013 pozostáva z 595 plôšok, ktoré sa od seba odlišujú na základe fyziognomických znakov a spôsobu využitia, ale tiež rôzne zastúpenými rastlinnými spoločenstvami. V niektorých areáloch však prevláda len riedka vegetácia na skalách, haldy hlušiny alebo umelé povrchy. V skúmanom území sme zaznamenali 52 TKP, z ktorých boli niektoré priradením váženého skóre hemeróbie rozdelené do určitých podtried - horné indexy (tab. 2). Týkalo sa to triedy 2.3.1.1 trávne porasty prevažne bez stromov a krov, 2.3.1.2 trávne porasty s rozptýlenými stromami a krami, 3.1.2.1 ihličnaté lesy so súvislým zápojom, 3.1.2.2 ihličnaté lesy s nesúvislým zápojom a 3.1.3.1 zmiešané lesy so súvislým zápojom. Celkový počet takto zaznamenaných tried predstavoval 58 položiek. Z hl'adiska rozlohy zaberala najväčšiu plochu trieda 3.1.3.1 ${ }^{\mathrm{b}}$ zmiešané lesy so súvislým zápojom a lokálnymi prejavmi t’ažby dreva (432,99 ha), čo predstavuje 32,28\% celkového územia a trieda 3.1.2.1 ihličnaté lesy so súvislým zápojom a lokálnymi prejavmi t’ažby dreva (356,14 ha) zaberajúca $26,55 \%$ celkového územia.

Vypočítaním IESK (tab. 3) sme zistili, že ekologická stabilita skúmaného územia je rovná hodnote 0,4 , čo zarad'uje skúmané územie medzi výrazne nestabilné oblasti. SHDI vážený hemeróbiou (obr. 2.) sa podiel'al na IESK hodnotami od 0 do 0,292 . Najväčšiu hodnotu 0,292 dosiahla trieda $3 \cdot 1.3 .1^{\mathrm{b}}$, čo predstavuje $20,6 \%$ $\mathrm{z}$ celkovej hodnoty. Podobne, takmer $20 \%$ pripadalo na triedu 3.1.2.1 ${ }^{\mathrm{b}} \mathrm{s}$ hodnotou 0,2816. Zaujímavým zistením bola skutočnost', že trieda 3.1.1.4 plantáže listnatých 
stromov, ktorú tvoria rozsiahlejšie porasty rýchlorastúcich prípravných drevín, napr. vŕba rakytová (Salix caprea), topol' osikový (Populus tremula), lieska obyčajná (Corylus avellana), brezy (Betula sp.), lipa malolistá (Tilia cordata), jarabina vtáčia (Sorbus aucuparia) a pod., sa na $S H E I^{h i}$ podiel'ala hodnotou 0,1392 $(8,14 \%)$. Trieda vznikla takmer úplným rozpadom lesných spoločenstiev po enormnom ataku imisiami z blízkeho NPZ. Prevažná väčšina týchto lesov je zaradená do kategórie lesov ochranných s prevažujúcou funkciou ochrany pôdy. Súčet všetkých týchto hodnôt tvoril 0,35. Dĺžka vodných tokov, ktoré si počas celého obdobia zachovali prirodzený tvar a neprechádzali urbanizovanými (technizovanými) a pol'nohospodarskými areálmi, predstavovala $11,24 \mathrm{~km}$. Poslednou súčast’ou je dlžka ekologických bariér, ktoré sme zaznamenali v severozápadnej časti katastrálneho územia. Za ekologickú bariéru sme pokladali úsek cesty III. triedy č. 3244 smerom na Poráč, ktorá prechádzala triedami $2.3 .1 .1^{2}, 3.1 .2 .1^{\mathrm{b}}$ a $3.1 .3 .1^{\mathrm{b}}$ $\mathrm{v}$ dlížke $2,8 \mathrm{~km}$.

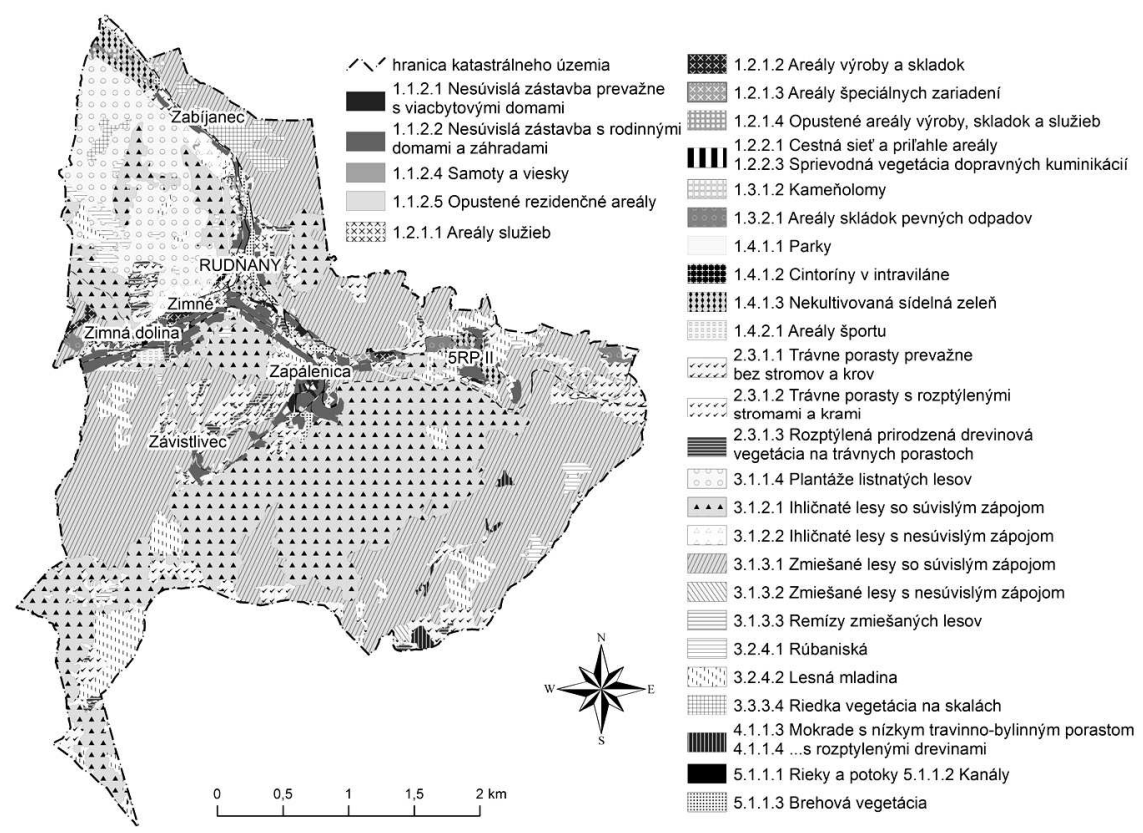

Obr. 1. Krajinná pokrývka v roku 2013 klasifikovaná metodikou CLC v mierke 1:10 000 a následne generalizovaná pre grafické zobrazenie

Relevantnost' použitých postupov naznačuje zaznamenanie zníženej hodnoty SHDI váženého hemeróbiou (obr. 2) v lokalite Stožky, na zvyškoch krasovej planiny severne od miestnej časti Zabíjanec a na banských haldách nachádzajúcich sa v miestnej časti Zimná dolina a 5RP II, ktorej súčast'ou je i rekultivované smetisko. Ide o najzat'aženejšie časti nachádzajúce sa v skúmanom území. Nízka stabilita bola v lokalite Stožky a na zvyškoch krasovej planiny vypočítaná aj napriek výskytu triedy 3.3.3.4 riedka vegetácia na skalách s váženým skóre hemeróbie 0,9 - oligohemeoróbny a tried 3.1.1.4, 3.1.2.1 ${ }^{\mathrm{b}}$ a $3.1 .3 .1^{\mathrm{b}} \mathrm{s}$ hemeróbiou 0,7 - mezohemeróbny. Dôvodom bola zvýšená fragmentácia krajiny spôsobená nahradením pô- 
vodných lesov rýchlorastúcimi prípravnými drevinami a vznik monokultúr ihličnatých lesov tvorených smrekom obyčajným (Picea abies), borovicou čiernou (Pinus nigra), borovicou lesnou (Pinus sylvestris) a smrekovcom opadavým (Larix decidua).

Tab. 2. Hodnoty vypočítaného indikátora ekologickej stability krajiny

\begin{tabular}{|c|c|c|c|c|c|c|c|}
\hline TKP & $\mathrm{h}_{\mathrm{i}}$ & $\mathrm{r}_{\mathrm{TKP}}$ & SHDI* $_{\mathrm{i}}$ & TKP & $\mathrm{h}_{\mathrm{i}}$ & $\mathrm{r}_{\mathrm{TKP}}$ & SHDI $^{*} h_{i}$ \\
\hline 1.1.2.1.1 & 0,1 & 3,84 & 0,0017 & 1.4 .2 .1 .2 & 0,0 & 0,14 & 0,0000 \\
\hline 1.1.2.2.1 & 0,1 & 23,82 & 0,0072 & $2.3 .1 .1^{4}$ & 0,4 & 2,10 & 0,0041 \\
\hline 1.1 .2 .2 .2 & 0,3 & 24,02 & 0,0216 & $2.3 .1 .1^{3}$ & 0,5 & 22,40 & 0,0342 \\
\hline 1.1.2.4 & 0,1 & 0,02 & 0,0000 & $2.3 .1 .1^{2}$ & 0,6 & 67,59 & 0,0904 \\
\hline 1.1.2.5 & 0,1 & 0,49 & 0,0003 & $2.3 .1 .1^{1}$ & 0,7 & 38,01 & 0,0706 \\
\hline 1.2.1.1.1 & 0,0 & 0,31 & 0,0000 & $2.3 .1 .2^{3}$ & 0,5 & 1,88 & 0,0046 \\
\hline 1.2.1.1.2 & 0,0 & 0,33 & 0,0000 & $2.3 .1 .2^{1}$ & 0,7 & 4,80 & 0,0142 \\
\hline 1.2 .1 .1 .3 & 0,0 & 0,23 & 0,0000 & 2.3.1.3.1 & 0,6 & 3,39 & 0,0090 \\
\hline 1.2.1.1.4 & 0,0 & 1,15 & 0,0000 & 2.3.1.3.2 & 0,6 & 5,85 & 0,0143 \\
\hline 1.2 .1 .1 .5 & 0,0 & 1,35 & 0,0000 & 2.3.1.3.3 & 0,6 & 3,42 & 0,0090 \\
\hline 1.2.1.1.6 & 0,0 & 0,43 & 0,0000 & 2.3.1.3.4 & 0,6 & 2,78 & 0,0078 \\
\hline 1.2.1.1.7 & 0,2 & 1,94 & 0,0018 & 3.1.1.4 & 0,7 & 104,46 & 0,1392 \\
\hline 1.2.1.2.1 & 0,0 & 2,80 & 0,0000 & $3.1 .2 .1^{c}$ & 0,7 & 29,88 & 0,0594 \\
\hline 1.2.1.2.3 & 0,2 & 1,55 & 0,0016 & $3.1 .2 .1^{\mathrm{b}}$ & 0,8 & 356,14 & 0,2816 \\
\hline 1.2.1.3.1 & 0,0 & 0,45 & 0,0000 & 3.1 .2 .2 & 0,7 & 12,45 & 0,0305 \\
\hline 1.2.1.3.1 & 0,2 & 0,24 & 0,0003 & $3.1 .3 .1^{c}$ & 0,7 & 15,21 & 0,0354 \\
\hline 1.2 .1 .4 & 0,0 & 2,86 & 0,0000 & $3.1 .3 .1^{\mathrm{b}}$ & 0,8 & 432,99 & 0,2920 \\
\hline 1.2 .2 .1 .2 & 0,0 & 11,56 & 0,0000 & 3.1.3.2 & 0,8 & 1,36 & 0,0055 \\
\hline 1.2.2.1.3 & 0,0 & 1,67 & 0,0000 & 3.1.3.3 & 0,8 & 0,93 & 0,0041 \\
\hline 1.2.2.1.5 & 0,0 & 0,11 & 0,0000 & 3.2 .4 .1 & 0,6 & 16,03 & 0,0319 \\
\hline 1.2 .2 .3 .1 & 0,2 & 0,42 & 0,0005 & 3.2 .4 .2 & 0,7 & 77,29 & 0,1151 \\
\hline 1.2 .2 .3 .3 & 0,2 & 0,17 & 0,0002 & 3.3.3.4 & 0,9 & 18,37 & 0,0529 \\
\hline 1.3 .1 .2 & 0,1 & 0,56 & 0,0003 & 4.1.1.3 & 0,9 & 2,69 & 0,0112 \\
\hline 1.3.2.1.1 & 0,1 & 7,86 & 0,0030 & 4.1.1.4 & 0,9 & 1,38 & 0,0062 \\
\hline 1.4.1.1.1 & 0,4 & 0,48 & 0,0013 & 5.1.1.1 & 0,5 & 0,16 & 0,0005 \\
\hline 1.4.1.1.2 & 0,4 & 0,10 & 0,0004 & 5.1.1.2 & 0,2 & 1,37 & 0,0014 \\
\hline 1.4.1.2 & 0,4 & 0,58 & 0,0012 & 5.1.1.3.1 & 0,5 & 3,57 & 0,0080 \\
\hline 1.4.1.3 & 0,4 & 14,69 & 0,0199 & 5.1.1.3.2 & 0,5 & 2,95 & 0,0067 \\
\hline 1.4.2.1.1 & 0,4 & 2,62 & 0,0050 & 5.1.1.3.3 & 0,5 & 5,03 & 0,0106 \\
\hline SHEI $^{\text {hi }}$ & & & & 0,35 & & & \\
\hline EK & & & & 0,10 & & & \\
\hline EB & & & & 0,05 & & & \\
\hline IESK & & & & 0,40 & & & \\
\hline
\end{tabular}

Vysvetlivky: TKP - triedy krajinnej pokrývky (pozri Ot’ahel' et al. 2017, pp. 196-205), $\mathrm{h}_{\mathrm{i}}$ - vážené skóre hemeróbie i-tej triedy

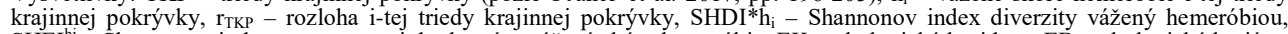
SHEI ${ }^{\text {hi }}$ - Shannonov index vyrovnanosti doplnený o vážené skóre hemeróbie, EK - ekologické koridory, EB - ekologické bariéry, IESK - indikátor ekologickej kvality (stability) krajiny, horné indexy - pozri tab. 1. 


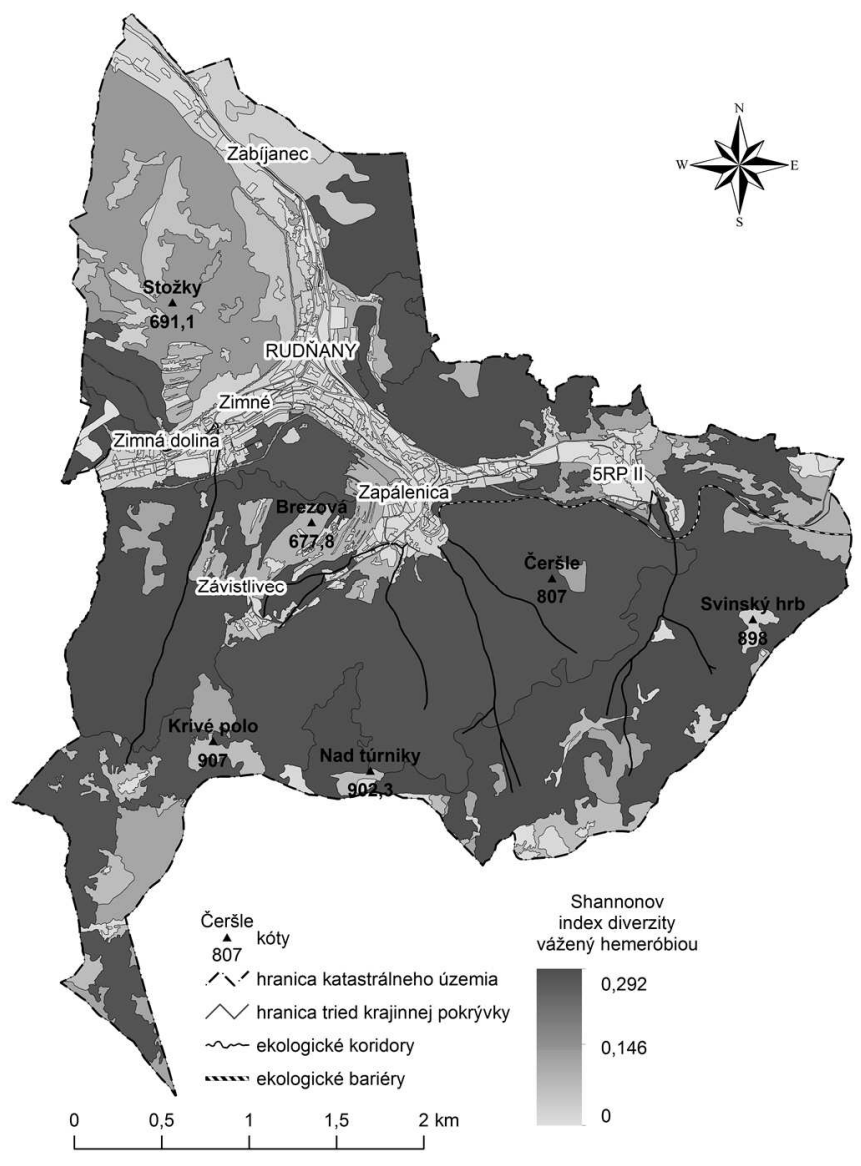

Obr. 2. Hodnota Shannonovho indexu diverzity váženého hemeróbiou jednotlivých tried krajinnej pokrývky

Na overenie hypotézy o zlepšení výsledkov IESK za použitia detailnejšieho členenia DKŠ aplikáciu modifikovanej metódy CLC a legendy v mierke 1:10 000 (Ot’ahel' et al. 2017) boli TKP prístupom ,zdola-nahor“" zatriedené do 4. a 3. hierarchickej úrovne. Zároveň sme použili dátovú vrstvu krajinnej pokrývky na 4. hierarchickej úrovni využívajúcu legendu spracovanú pre krajinnoekologický výskumu pre krajiny programu PHARE v mierke 1:50 000 (Feranec a Ot'ahel' 1999) s rešpektovaním minimálneho mapovaného areálu 4 ha (tab. 3.). Celkový počet delimitovaných tried sa z pôvodných 58 znížil až na 15 . V skúmanom území sme zachytili pokles diverzity krajiny, resp. Shannonovho indexu diverzity (SHDI), ktorého hodnota klesala znižovaním počtu tried. Dôkazom o vyššom stupni rovnomernosti zastúpenia jednotlivých tried bol vypočítaný Shanonov index vyrovnanosti (SHEI), ktorého hodnota rástla od 5. $(0,56)$ po 3. $(0,66)$ hierarchickú úroveň. Najvyššiu vyrovnanost' $(0,71)$ sme zaznamenali $\mathrm{v}$ rámci metódy CLC na mapovanie $\mathrm{v}$ mierke 1:50 000. V prípade IESK dochádzalo k nárastu jeho hodnoty, ktorá bola spôsobená zvyšovaním vyrovnanosti a znižovaním váženého skóre hemeróbie pri triedach, 
ktoré sa „zdola nahor“ stávali heterogénnejšie. Poukazuje to na negatívny vzt'ah medzi IESK a počtom zaznamenaných tried v skúmanom území. Nižšiu hodnotu IESK možno považovat' za schopnost' detailnejšie poznat' reálny stav DKŠs, ktorá sa odráža v jej ekologickej stabilite. Hodnota úzko súvisí s mierkou a obsahom identifikovaných krajinných prvkov, ktoré určujú kvalitu (detailnost') priestorového a obsahového poznania (homogénnost') tried krajinnej pokrývky.

Prekrytím vrstvy krajinnej pokrývky pravidelnou štvorcovou siet'ou s vel'kost'ou štvorca 1 ha $(100 \times 100 \mathrm{~m})$ sme získali 1470 štvorcov. Z toho bolo 1200 úplných a 270 neúplných štvorcov, ktoré sa nachádzali po obvode študovaného územia. V štvorcovej sieti bola najčastejšie prítomná jedna TKP, ktorej podiel predstavoval $36,6 \%$ (538 štvorcov). Dalších $32,2 \%$ pripadalo na štvorce s výskytom dvoch tried (458 štvorcov) a 14 \% na štvorce s výskytom troch tried (207 štvorcov). Počet štvorcov s vyšším počtom tried mal klesajúcu tendenciu. Vel'mi málo boli v krajinnej mozaike zastúpené štvorce s výskytom 10 až 12 tried. Ich podiel predstavoval necelých $1,5 \%$.

Tab. 3. Porovnávanie výsledných hodnôt pre vrstvu krajinnej pokrývky na 5. až 3. hierarchickej úrovni

\begin{tabular}{ccccc}
\hline Hierarchická úroveň & $\mathrm{s}$ & SHDI & SHEI & IESK \\
\hline 5. & 58 & 2,28 & 0,56 & 0,4 \\
4.1 & 39 & 2,21 & 0,6 & 0,43 \\
4.2 & 16 & 1,98 & 0,71 & 0,49 \\
3. & 15 & 1,8 & 0,66 & 0,5
\end{tabular}

Vysvetlivky: 4.1 - 4. hierarchická úroveň (,zdola nahor“), 4.2 - 4. hierarchická úroveň (min. mapovaný areál 4 ha), s - celkový počet tried krajinnej pokrývky v analyzovanej priestorovej jednotke, SHDI - Shannonov index diverzity, SHEI - Shannonov index vyrovnanosti, IESK - index ekologickej stability krajiny.

Štvorce s vyšším počtom tried boli koncentrované v doline Rudnianskeho potoka (centrálna čast' obce) a Zimnej doline.

Ekologickú stabilitu v každom štvorci sme vypočítali podl'a IESK. Z dôvodu vzniku vel'kého množstva plôšok menších ako minimálny mapovaný areál 0,1 ha bol SHEI ${ }^{h i}$ prepočítaný v metroch štvorcových a dížka ekologických koridorov a bariér identifikovaná pre jednotlivé štvorce. IESK nadobúdal hodnoty od $-0,27$ do 1,12 (obr. 3.).

Najnižšie (mínusové) hodnoty boli zaznamenané v 21 štvorcoch, ktorými prechádzala ekologická bariéra. Vysoké hodnoty IESK (od 1,12 do 0,75) boli vypočítané v 47 štvorcoch, kde dochádzalo $\mathrm{k}$ prechodu medzi triedami trávne porasty (2.3.1.1), rozptýlená prirodzená vegetácia na trávnych porastoch (2.3.1.3), triedami lesa $(3.1 .1 .4,3.1 .2 .1,3.1 .2 .2,3.1 .3 .1$ a 3.2.3.2), lesná mladina (3.2.4.2), riedka vegetácia na skalách (3.3.3.4) a mokrade (4.1.1.3 a 4.1.1.4). Jedným z hlavných dôvodov vysokej hodnoty IESK bol relatívne vysoký stupeň rovnomernosti zastúpenia jednotlivých tried (od 0,84 do 0,75 ) charakteristický pre $30 \mathrm{z}$ celkového počtu 47 štvorcov a na druhej strane prítomnost' prirodzeného stavu vodných tokov (ekologických koridorov) vo zvyšných 17 štvorcoch, kde sa výsledná hodnota EK pohybovala od 0,45 do 0,15 . V súčasnom chápaní krajinnej ekológie môžu tieto 
prechody medzi TKP predstavovat' ekotony, prechodné zóny medzi susediacimi ekosystémami, ktoré sú jednoznačne definované v priestore, čase a silnou interakciou medzi susediacimi ekosystémami. Zároveň môžu mat' aj väčšiu druhovú pestrost' ako samotné okolité biotopy. Štvorce s vysokou hodnotou IESK boli identifikované aj v intraviláne a jeho tesnej blízkosti, pozdĺž cesty smerom na Poráč a do miestnej časti Závistlivec. Dôvodom bola prítomnost' ekologických koridorov, ktoré zvýšili výslednú hodnotu IESK o 0,2 až 0,5 . Určitou nevýhodou pri výpočte IESK $v$ pravidelnej štvorcovej sieti sú štvorce $s$ prítomnost'ou iba jednej TKP. $\mathrm{V}$ takomto prípade je diverzita krajiny a jej vyrovnanost' $\mathrm{v}$ rámci analyzovanej priestorovej jednotky nulová.

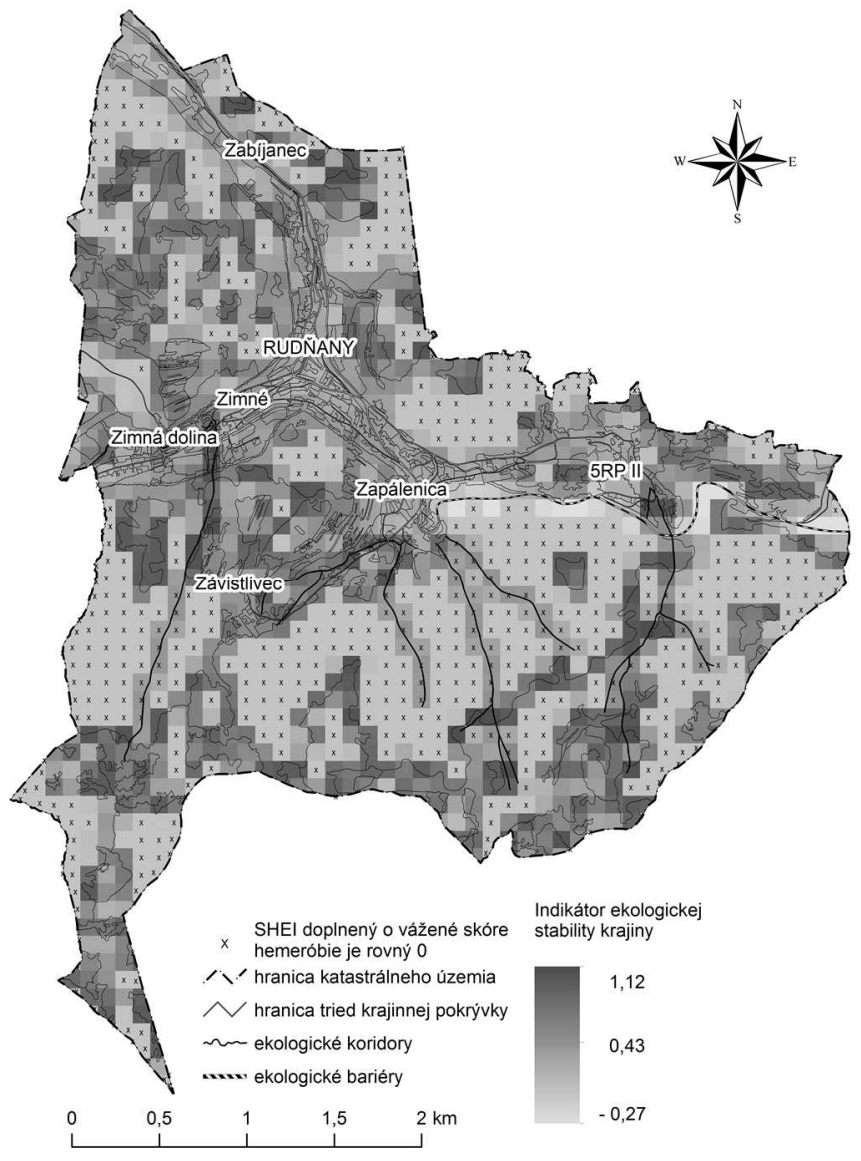

Obr. 3. Indikátor ekologickej stability krajiny vypočítaný v štvorcovej sieti $(100 \times 100 \mathrm{~m})$

\section{DISKUSIA A ZÁVER}

Krajinnú štruktúru môžeme chápat' ako zákonité priestorové rozloženie kvantitatívnych a kvalitatívnych vlastností krajiny, ktoré sa v zmysle práce Ružička (2001) spájajú do komplexných fyziognomicko-ekologických alebo funkčných celkov. Ak hodnotíme celkový počet i rovnomernost' rozmiestnenia krajinných 
prvkov vo vzt'ahu k pôvodnému alebo optimálnemu stavu krajiny, môžeme hodnotit' mieru antropogénnej premeny jej súčasnej (druhotnej) krajinnej štruktúry. $\mathrm{V}$ rámci DKŠ môžeme krajinné prvky vyčlenit' na základe fyziognomickomorfoštruktúrnych, resp. ekologických (Miklós a Izakovičová 1997) charakteristík ako prvky krajinnej pokrývky. Pri detailnejšom členení DKŠ použitím legendy krajinnej pokrývky na 5. hierarchickej úrovni (Ot'ahel' et al. 2017) sa nám podarilo podrobne zaznamenat' aktuálny stav krajiny a $\mathrm{v}$ rámci urbanizovaných a technizovaných areálov vyčlenit' všetky vyskytujúce sa triedy (záhrady pri rodinných domoch, prevažne kultivovaná zeleň $v$ areáloch služieb, sprievodná vegetácia v areáloch výroby, sprievodná vegetácia v areáloch špecializovaných zariadení, sprievodná vegetácia dopravných komunikácií), ktoré svojím podielom biotickej zložky pomáhajú zvyšovat' odolnost' alebo pružnost' stability krajiny.

Zachytenie negatívneho vzt'ahu medzi počtom tried a IESK vypočítaným pre environmentálne zat'ažené územie sa zhoduje s výsledkami práce SowińskaŚwierkos (2017), ktorá podobne zaregistrovala pokles výslednej hodnoty indikátora s nárastom počtu zaznamenaných TKP $\mathrm{v}$ územiach s rôznym stupňom ochrany prírody a krajiny. Toto zistenie nie je v súlade s výsledkami publikovanými autormi Poggio et al. (2010) a Schippers et al. (2015), ktoré naznačujú, že rôzne environmentálne podmienky majú za následok výskyt väčšieho počtu biotopov (tried krajinnej pokrývky), ktoré vytvárajú základ pre vývoj väčšieho počtu druhov. Na druhej strane, práve rozlohou väčšie prírodné a poloprírodné typy TKP znamenajú existenciu stabilnejších populácií, nižšiu pravdepodobnost' vyhynutia a vyššiu mieru rekolonizácie (Hanski 1999). Z toho dôvodu môžeme predpokladat', že vyššia miera diverzity a ekologickej stability je zabezpečená prostredníctvom rozlohou väčších TKP (Wilson et al. 2009). Tento negatívny vzt'ah medzi počtom TKP a IESK svedčí o správnosti použitia váženého skóre hemeróbie $\left(h_{i}\right)$ pri výpočte Shannonovho indexu vyrovnanosti (SHEI). Ako d'alej popisuje Sowińska-Świerkos (2017), tento index nie je možné použit’ bez predchádzajúceho empirického pozorovania alebo skúsenosti. Nemalo by íst' len o teoretické odčítanie hodnôt, pretože index priamo neodzrkadl'uje ekologickú stabilitu skúmaného územia. Preto je pri jednotlivých TKP potrebné dostatočne zvážit' ich zaradenie do váženého skóre hemeróbie prihliadajúc na celkový stav DKS̆, históriu využívania a ich homogénnost'. Zohl'adnenie ekologickej významnosti je v súlade s prácami Löw (1984), Miklós (1986) a Reháčková a Pauditšová (2007). Rôzne TKP majú rôznu ekologickú významnost', na čo vo svojej práci poukázali Ot’ahel' et al. (2004) stanovením podielu biotickej zložky (hodnotením charakteru a funkcie vegetácie) jednotlivých tried.

Hodnotenie mriežkovým prístupom prispelo k zlepšeniu predstavy o priestorovej diferenciácii ekologickej stability krajiny a umožnilo zistit', v ktorých častiach územia nadobúda IESK vysoké hodnoty. Vysoké hodnoty sme pozorovali v prechodných zónach (ekotonoch) medzi susediacimi TKP s vysokým stupňom rovnomerného priestorového zastúpenia, potenciálne vyššou diverzitou krajiny, čo je typické pre antropogénnou činnostou významne pozmenené územia. Výsledky sa zhodujú s hodnotením ekologickej významnosti antropicky podmienených ekotonov lesnej vegetácie v Starohorských vrchoch (Gajdoš et al. 2012). V rámci existencie ekotonov je potrebné brat' do úvahy postupné a náhle (nárazové) zmeny v priestore a čase. K náhlym priestorovým a časovým zmenám dochádza najčastejšie vplyvom nepredvídatel’ných disturbancií charakteristických nelineárnym a chaotickými správaním, ktorých činnost'ou novovzniknuté okraje krajinných prvkov 
možno považovat' za ekotony. Ak dochádza k sérii priestorových a časových zmien (tzn. štrukturálne a funkčné zmeny medzi susediacimi ekosystémami majú určitý lineárny charakter), je lepšie tieto okraje označovat' ako ekolínie (ekologické gradienty), ktoré sú výsledkom pôsobenia ekologickej sukcesie. Z priestorového a časového hl'adiska však nemožno ekotony považovat' za stabilné krajinné prvky, pretože ich prítomnost' a neprítomnost' v značnej miere závisí od miery antopogénneho vplyvu a nástupu sukcesie.

V d'alšej štúdii by bolo potrebné preskúmat' vplyv ekotonov na stabilitu krajiny. Ako d'alej poukazuje Levins (1970), teória metapopulácie predstavuje lepší model fungovania fragmentovaného terestriálneho systému. Súčasne metapopulačné modely predpokladajú, že populácia určitého územia pozostáva z niekol'kých subpopulácií. Každá subpopulácia osídl'uje určitý biotop s charakteristickými environmentálnymi podmienkami, ktoré sú navzájom poprepájané hraničnými zónami (ekotony) zabezpečujúcimi interakciu medzi susednými krajinnými prvkami (Merriam a Wegner 1992). Z toho dôvodu môžeme ekotony považovat' za samostatné ekologické jednotky (Turner et al. 1991) alebo jedinečné biotopy (Hansen et al. 1988) vytvárajúce optimálne životné prostredie niektorým rastlinným a živočíšnym druhom.

Zachytenie ekologickej významnosti jednotlivých TKP len pomocou stupňa hemeróbie možno pokladat' za vel'mi obmedzujúce. S iným pohl'adom na ekologickú stabilitu prišli Buček a Lacina (1995), ktorí rozlišujú vnútornú a vonkajšiu ekologickú stabilitu. Za vhodný indikátor vysokej vnútornej ekologickej stability možno považovat' klimaxové štádium ekologickej sukcesie. Táto sa prejavuje najmä v osobitne chránených územiach s vyšším stupňom ochrany, napríklad v pralesoch. Kým vonkajšiu ekologickú stabilitu, ako schopnost' ekosystému odolávat' rušivým vplyvom, dobrým spôsobom vystihuje hemeróbia. Za objektívne kritérium pri hodnotení ekologickej stability možno považovat' stupeň prirodzenosti ekosystému (sukcesné štádium), ako hodnotu nepriamo úmernú stupňu hemeróbie. Vytvára sa tak priestor pre d'alšie zdokonal'ovanie predkladaného indikátora a presnejšie určenie ekologickej významnosti krajinných prvkov, osobitne pri alternatívnom hodnotení chránených území.

Príspevok vznikol v rámci riešenia grantového výskumného projektu VEGA č. 1/0247/19 „Hodnotenie dynamiky využitia krajiny a zmien krajinnej pokrývky“, VEGA č. 1/0052/17 „Primestská krajina: analýza zmien krajinnej pokrývky a organizácie socioekonomických funkcii vplyvom urbanizačných a suburbanizačných procesov" a bol podporený grantom Univerzity Komenského č. UK/205/2018.

\section{LITERATÚRA}

ARAGON, R., OESTERHELD, M., IRISARRI, G., TEXEIRA, M. (2011). Stability of ecosystem functioning and diversity of grasslands at the landscape scale. Landscape Ecology, 26, 1011-1022. DOI: https://doi.org/10.1007/s10980-011-9625-z.

BOLTIŽIAR, M. (2010). Analýza vývoja heterogenity a vybraných vlastností plôšok štruktúry vysokohorskej krajiny (na príklade vybraných modelových území Tatier). Folia Geographica, 16, 105-124.

BOLTIŻIAR, M., OLÁH, B. (2009). Krajina a jej štruktúra (mapovanie, zmeny a hodnotenie). Nitra (UKF v Nitre).

BUČEK, A., LACINA, J. (1995). Diferenciace krajiny v geobiocenologickém pojetí a její aplikace v krajinném plánování při navrhování územních systémů ekologické stability, Zprávy České botanické společnosti, Praha, 30, Mater. 12, 90-102. 
ČECH, V., KROKUSOVÁ, J. (2013). Antropogénna geomorfológia (antropogénne formy georeliéfu). Prešov (Grafotlač Prešov).

DALlEAU, M., ANDREFOUET, S., WABNITZ, C. C., PAYRI, C., WANTIEZ, L., PICHON, M., FRIEDMAN, K., VIGLIOLA, L., BENZONI, F. (2010). Use of habitats as surrogates of biodiversity for efficient coral reef conservation planning in Pacific Ocean islands. Conservation Biology, 24, 541-552. DOI: https://doi.org/10.1111/j.15231739.2009.01394.X.

DRUGA, M., MINÁR, J. (2018). Exposure to human influence - a geographical field approximating intensity of human influence on landscape structure. Journal of Maps, 14, 486-493. DOI: https://doi.org/10.1080/17445647.2018.1493408.

EWERS, R. M., DIDHAM, R. K., WRATTEN, S. D., TYLIANAKIS, J. M. (2005). Remotely sensed landscape heterogeneity as a rapid tool for assessing local biodiversity value in a highly modified New Zealand landscape. Biological Conservation, 14, 14691485. DOI: https://doi.org/10.1007/s10531-004-9786-z.

FAZEKAŠ, J., FAZEKAŠOVÁ, D., HRONEC, O., BENKOVÁ, E., BOLTIŽIAR, M. (2018). Contamination of soil and vegetation at a magnesite mining area of JelšavaLubeník (Slovakia). Ekológia (Bratislava), 37, 101-111. DOI: https://doi.org/10.2478/ eko-2018-0010.

FERANEC, J., OŤAHEL, J. (1999). Mapovanie krajinnej pokrývky metódou CORINE v mierke 1:50 000: návrh legendy pre krajiny programu Phare. Geografický časopis, 51, 19-35.

FORMAN, R. T. T., ALEXANDER, L. E. (1998). Roads and their major ecological effects. Annual Review of Ecology and Systematics, 29, 207-231.

FORMAN, R. T. T., GODRON, M. (1993), Krajinná ekologie. Praha (Academia).

GAJDOŠ, A., KLAUČO, M., ŠKODOVÁ, M. (2012). Hodnotenie krajinnej štruktúry a ekologickej významnosti ekotonov lesnej vegetácie v Starohorských vrchoch. Geografický časopis, 64, 253-266.

GASCON, C., LOVEJOY, T. E., BIERREGAARD Jr, R. O., MALCOM, J. R., STOUFFER, P. C., VASCONCELOS, H. L., WILLIAM, F. L., ZIMMERMAN, B., TOCHER, M., BORGES, S. (1999). Matrix habitat and species richness in tropical forest remnants. Biological Conservation, 91(2-3), 223-229. DOI: https://doi.org/10.1016/S0006-3207 (99)00080-4.

HANSEN, A. J., di CASTRI, F., NAIMAN, R. J. (1988). Ecotones: what and why. Biology International, 17, 9-46.

HANSKI, I. (1999). Metapopulation Ecology. Oxford (Oxford University Press).

HANUŠIN, J., ŠTEFUNKOVÁ, D. (2015). Zmeny diverzity vinohradníckej krajiny v zázemí Svätého Jura v období 1896 - 2011. Geografický časopis, 67, 219-241.

IVANOVÁ, M., MICHAELI, E., BOLTIŽIAR, M. (2013a). Analýza zmien priestorovej štruktúry krajinnej pokrývky územia severne od vodnej nádrže Zemplínska šírava. Geografický časopis, 65, 235-250.

IVANOVÄ, M., MICHAELI, E., BOLTIŽIAR, M., FAZEKAŠOVÁ, D. (2013b). The analysis of changes ecological stability of landscape in the contrasting region of the mountain range and a lowland. In International Multidisciplinary Scientific GeoConference : SGEM : Surveying Geology \& mining Ecology Management, Sofia 1. pp. 925-938.

IVANOVÁ, M., MICHAELI, E., BOLTIŽIAR, M., JUHAŠČ́́KOVÁ, J. (2011). Analysis of landscape heterogeneity changes on the example of Hlinné, Vyšný Žipov, and Zlatník village (Eastern Slovakia) in the period 1826 - 2006. Ekológia (Bratislava), 30, 269280.

IZAKOVIČOVÁ, Z., ed. (1999). Hodnotenie súčasnej krajinnej štruktúry v metodikách krajinnoekologického mapovania. In Izakovičová, Z., ed. Zmeny krajinnej štruktúry v kontexte trvalo udržatelného rozvoja. Zborník príspevkov zo IV. Odborného șeminára z cyklu Diskusia ku koncepcii trvalo udržatel’ného rozvoja, Nitra. Bratislava (ÚKE SAV), pp. 59-63. 
JAEGER, J. A. G., FAHRIG, L. (2004). Effects of road fencing on population persistence. Conservation Biology, 18, 1651-1657. DOI: https://doi.org/10.1111/j.1523-1739. 2004.00304.x.

JURKO, A. (1990). Ekologické a socioekonomické hodnotenie vegetácie. Bratislava (Príroda).

KARLSON, M., MÖRTBERG, U., BALFORS, B. (2014). Road ecology in environmental impact assessment. Environmental Impact Assessment Review, 48, 10-19. DOI: https:// doi.org/10.1016/j.eiar.2014.04.002.

KLEESCHULTE, S., SOUKUP, T., HAZEU, G., SMITH, G., ARNOLD, S., KOSZTRA, B. (2016). Future of land monitoring in Europe. In Feranec, J., Soukup, T., Hazeu, G., Jaffrain, G., eds. European landscape dynamics: CORINE land cover dat. Boca Raton (CRC Press), 319-328.

KOPECKÁ, M. (2011). Indikátory hodnotenia diverzity krajiny. Životné prostredie, 45, 198-202.

LAPIN, M., FAŠKO, P., MELO, M., ŠŤASTNÝ, P., TOMLAIN, J. (2002). Klimatické oblasti 1:1 000 000. In Atlas krajiny Slovenskej republiky. Bratislava (Ministerstvo životného prostredia SR) a Banská Bystrica (Slovenská agentúra životného prostredia), p. 95.

LESKOVJANSKÁ, A., DRAŽIL, T., LESKOVJANSKÝ, M. (2013). Územný systém ekologickej stability Rudňany. Spišská Nová Ves (Ligularia, s.r.o.).

LEVINS, R. (1970) Extinction. In Gerstenhaber, M., ed. Some mathematical questions in biology. Vol. 2. Lectures on mathematics in the life sciences. Rhode Island (American Mathematical Society, Providence), pp. 77-107.

LIN, T., GE, R., HUANG, J., ZHAO, Q., LINA, J., HUANG, N., ZHANG, G., LI, X., YE, H., YIN, K. (2016). A quantitative method to assess the ecological indicator system's effectiveness: a case study of the ecological province construction indicators of China. Ecological Indicators. 62, 95-100. DOI: https://doi.org/10.1016/j.ecolind.2015.11.027.

LIŠČÁK, P., BAJTOŠ, P., MAŠLÁR, E., MAŚLÁROVÄ, I. (2016). Vplyv t’ažby nerastov na životné prostredie, [Online]. Dostupné na: http://dionysos.gssr.sk/cmsgf/files/ Hodn monitor 2015/04 Vplyv tazby 2015.pdf [cit.: 17-7-2018].

LÖW, J. (1984). Zásady pro vymezování a navrhovani územních systému ekologické stability v územne-plánovací praxi. Brno (Agroprojekt Brno).

MACKOVČIN, P. (2000). A multi-level ecological network in the Czech Republic: implementing the territorial system of ecological stability. GeoJournal, 51, 211-220. DOI: https://doi.org/10.1023/A:101751852.

MAZUR, E., LUKNIŠ, M. (1986). Geomorfologické členenie SSR. 1:500 000. Bratislava (Slovenská kartografia).

MELLO, J., FILO, I., HAVRILA, M. (2000). Vysvetlivky ku geologickej mape Slovenského raja, Galmusu a Hornádskej kotliny 1: 50 000. Bratislava (Geologický ústav D. Štúra).

MERRIAM, G., WEGNER, J. (1992). Local extinctions, habitat fragmentation, and ecotones. In Hansen, A. J., di Castri, F., eds. Landscape boundaries: consequences for biotic diversity and ecological flows. New York (Springer), pp. 150-169.

MÍCHAL, I. (1994). Ekologická stabilita. Brno (MŽP CR).

MIKLÓS, L. (1986). Stabilita krajiny v ekologickom genereli SSR. Životné prostredie, 20, 87-93.

MIKLÓS, L., IZAKOVIČOVÁ, Z. (1997). Krajina ako geosystém. Bratislava (SAV).

MINISTERSTVO ŽIVOTNÉHO PROSTREDIA SR (2005). Správa o stave životného prostredia Slovenskej republiky v roku 2005, [Online]. Dostupné na: https:// www.enviroportal.sk/uploads/spravy/2005-05-envi-regionaliz.pdf [cit.: 24-7-2018].

MUCHOVÁ, Z., TÁRNIKOVÁ, M. (2018). Land cover change and its influence on the assessment of the ecological stability. Applied Ecology and Environmental Research, 16, 2169-2182. DOI: http://dx.doi.org/10.15666/aeer/1603_21692182. 
OLÁHOVÁ, J., VOJTEK, M., BOLTIŽIAR, M. (2013). Assessment of landscape stability using variation curves. In 14th International scientific conference of PhD. students, young scientists and pedagogues. Nitra (FPV UKF), pp. 282-288.

OŤAHEL', J. (2011). Diverzita krajiny: miera diferenciácie prírodných podmienok a využívanie krajiny. Životné prostredie, 45, 176-181.

OŤAHEL, J., FERANEC, J., CEBECAUER, T., PRAVDA, J., HUSÁR, K. (2004). Krajinná štruktúra okresu Skalica. Geographia Slovaca, 19. Bratislava (Geografický ústav SAV).

OŤAHEL, J., FERANEC, KOPECKÁ, M., FALŤAN, V. (2017). Modifikácia metódy CORINE Land Cover a legenda pre identifikáciu a zaznamenávanie tried krajinnej pokrývky v mierke 1:10 000 na báze príkladových štúdií z územia Slovenska. Geografický časopis, 69, 189-224.

PAUDITSSOVÂ, E. (2010). Miestny územný systém ekologickej stability v projektoch pozemkových úprav. In Kozová, M., Pauditšová, E., Finka, M., eds. Krajinné plánovanie. Bratislava (Slovenská technická univerzita), pp. 281-286.

PEANO, A., CASSATELLA, C. (2011). Landscape assessment a monitoring. In Cassatella, C., Peano, A., eds. Landscape indicators: assessing and monitoring landscape quality. Milan (Springer).

PIERSON, J. C., BARTON, P. S., LANE, P. W., LINDENMAYER, D. B. (2015). Can habitat surrogates predict the response of target species to landscape change? Biological Conservation, 184, 1-10. DOI: https://doi.org/10.1016/j.biocon.2014.12.017.

POGGIO, S. L., CHANETON, E. J., GHERSA, C. M. (2010). Landscape complexity differentially affects alpha, beta, and gamma diversities of plants occurring in fencerows and crop fields. Biological Conservation, 143, 2477-2486. DOI: https://doi.org/10.1016/ j.biocon.2010.06.014.

PRAMUK, V., MATIOVÁ, Z. (2015). Prieskum pravdepodobnej environmentálnej zátaže SN (006) / Rudñany - t’ažba a úprava rúd, SK/EZ/SN/899. Záverečná správa. Košice (GEO Slovakia, s.r.o.).

RAMEZANI, H. (2012). A note on the normalized definition of Shannon's diversity index in landscape pattern analysis. Environment and Natural Resources Research, 2(4), 54-60.

REHÁČKOVÁ, T., PAUDITŠOVÁ E. (2007). Metodický postup stanovenia koeficientu ekologickej stability krajiny. Acta Environmentalica Universitatis Comenianae (Bratislava), 15, 26-38.

REHÁCKOVÁ, T., PAUDITŠOVÁ E., HREŠKO, J. (2008). Ekologická stabilita a manažment krajiny v k. ú. Sveržov. Geographia Cassoviensis, 2, 146-151.

RÜDISSER, J., TASSER, E., TAPPEINER, U. (2012). Distance to nature - a new biodiversity relevant environmental indicator set at the landscape level. Ecological Indicators, 15, 208-216. DOI: https://doi.org/10.1016/j.ecolind.2011.09.027.

RUŽIČKA, M. (2001). Krajinná štruktúra ako základ ekologických podkladov o krajine. In Izakovičová, Z., ed. Zmeny krajinnej štruktúry v kontexte trvalo udržatel’ného rozvoja. Bratislava (UKE SAV), pp. 5-13.

SHANNON, C. E. (1948). A mathematical theory of communications. Bell System Technical Journal, 27, 379-423.

SCHIPPERS, P., van der HEIDE, C. M., KOELEWIJN, H. P., SCHOUTEN, M. A., SMULDERS, R. M., COBBEN, M. M. P., STERK, M., VOS, C. C., VERBOOM, J. (2015). Landscape diversity enhances the resilience of populations, ecosystems and local economy in rural areas. Landscape Ecology, 30, 193-202. DOI: https:// doi.org/10.1007/s10980-014-0136-6.

SOWIŃSKA-ŚWIERKOSZ, B. (2017). Application of surrogate measures of ecological quality assessment: The introduction of the Indicator of Ecological Landscape Quality (IELQ). Ecological Indicators, 73, 224-234. DOI: https://doi.org/10.1016/j.ecolind. 2016.09.019. 
SOWIŃSKA-ŚWIERKOSZ, B. N., SOSZYŃSKI, D. (2014). Landscape structure versus the effectiveness of nature conservation: Roztocze region case study (Poland). Ecological Indicators, 43, 143-153. DOI: https://doi.org/10.1016/j.ecolind.2014.02.018.

STRED̆ANSKÝ, J., ŠIMONIDES, I. (1995). Tvorba krajiny. Nitra (AF VŠP).

SU, S., XIAO, R., LI, D. (2014). Impacts of transportation routes on landscape diversity: a comparison of different route types and their combined effects. Environmental management, 53, 636-647. DOI: https://doi.org/10.1007/s00267-013-0214-6.

TALLIS, H. T., RICKETTS, T., GUERRY, A. D., WOOD, S. A., SHARP, R., NELSON, E., ENNAANAY, D., WOLNY, S., OLWERA, N., VIGERSTOL, K., PENNINGTON, D., MENDOZA, G., AUKEMA, J., FOSTER, J., FORREST, J., CAMERON, D., ARKEMA, K., LONSDORF, E., KENNEDY, C., VERUTES, G., KIM, C. K., GUANNEL, G., PAPENFUS, M., TOFT, J., MARSIK, M., BERNHARDT, J. (2011). InVEST 2.4.4 User's Guide. The Natural Capital Project, Stanford, [Online]. Available: http:// data.naturalcapitalproject.org/invest-releases/documentation/2_4_4/ [accessed 2 July 2018].

TERRADO, M., SABATER, S., CHAPLIN-KRAMER, B., MANDLE, L., ZIV, G., ACUÑA, V. (2016). Model development for the assessment of terrestrial and aquatic habitat quality in conservation planning. Science of the Total Environment, 540, 63-70. DOI: https://doi.org/10.1016/j.scitotenv.2015.03.064.

TREMBOŠ, P. (2002). Hodnotenie ekologickej stability krajiny - modelový príklad Piešt’any. Folia Geographica, 6, 282-286.

TURNER, M. G. (1987). Spatial simulation of landscape changes in Georgia: a comparison of 3 transition models. Landscape Ecology, 1, 29-36.

TURNER, M. G., GARDNER, R. H., O'NEILL, R. V. (1991). Potential responses of landscape boundaries to global environmental change. In Holland, M. M., Rissen, P. G., Naiman, R. J., eds. Ecotones: the role of landscape boundaries in the management and restoration of changing environments. New York (Chapman and Hall), pp. 52-75.

Van der REE, R., JAEGER, J. A., Van der GRIFT, E. A., CLEVENGER, A. P. (2011). Effects of roads and traffic on wildlife populations and landscape function: road ecology is moving toward larger scales. Ecology and Society, 16, 48. [Online]. Dostupné na: https://www.ecologyandsociety.org/vol16/iss1/art48/ [cit: 10-7-2018].

VERSTAETE, J., HALLEZ, A., De TRE, G. (2007). Fuzzy regions: theory and applications. In Morris, A., Kokhan, S., eds. Geographic uncertainty in environmental security. Dordrecht (Springer) pp. 1-17. DOI: https://doi.org/10.1007/978-1-4020-6438-8_1.

WALZ, U., STEIN, C. (2014). Indicators of hemeroby for the monitoring of landscapes in Germany. Journal for Nature Conservation, 22, 279-289. DOI: https://doi.org/10.1016/ j.jnc.2014.01.007.

WILSON, T. L., JOHNSON, E. J., BISSONETTE, J. A. (2009). Relative importance of habitat area and isolation for bird occurrence patterns in a naturally patchy landscape. Landscape Ecology, 24, 351-360. DOI: https://doi.org/10.1007/s10980-008-9309-5.

WITTIG, R. (1998). Flora und vegetation. In Sukkop, H., Wittig R., eds. Stadtökologie. Ein Fachbuch für Studium und Praxis. Stuttgart (Gustav Fischer Verlag), pp. 219-265.

ŽIGRAI, F. (2001). Interpretácia historických máp pre štúdium využitia zeme a krajinnoekologický výskum. In: Kováčová, M., Hájek, M., eds. Historické mapy. Bratislava (KS SR), pp. 35-40. 
Matej Hrǔ̌ka, Vladimír F a lt’a n, Monika I va nová

\section{IMPLEMENTATION OF ALTERNATIVE ASSESSMENTS OF ECOLOGICAL STABILITY OF LANDSCAPE: A CASE STUDY OF THE ENVIRONMENTALLY AFFECTED AREA OF RUDŇANY}

Among the most effective tools for assessing the ecological landscape stability are different indicators. Within the framework of a geographical and landscape ecological research, ecological stability is often determined by calculating a coefficient of ecological landscape stability and using landscape-ecological indices. Landscape-ecological indices provide an image of the development of landscape and partly of its eco-stabilizing capability. The main aim of this paper is an attempt to synthesize the various forms of evaluation of the ecological stability of the cultural landscape and the use of the nomenclature for the identification and inventorying of land cover classes at a scale of 1:10 000 (Ot'ahel' et al. 2017).

A land cover map showing the real situation for the year 2013 was manually vectorized on the basis of a visual interpretation of aerial photography with the resolution of the raster $0.5 \mathrm{~m}$. Delineated land cover classes were assigned to the weighting score of hemeroby according to the studies conducted in the Central European environment and mapping of the current vegetation and biotopes. An alternative landscape-based approach was used for the quantification of the ecological landscape stability. The modified Indicator of Ecological Landscape Quality/Stability - IELS (Sowińska-Świerkosz 2017) was calculated for the whole study area and also separately for the grid areas of the size $100 \times 100 \mathrm{~m}$. The IELS is based on the use of normalized Shannon diversity index (Ramezani 2012) weighted hemeroby and the character of linear landscape structures (ecological lines and barriers).

The resulted value of IELS for the environmental affected area Rudňany (Eastern Slovakia) was 0.4 which ranks the area as between significantly unstabilized. The highest landscape diversity - Shannon diversity index (SHDI) modified by a weighting score of hemeroby were noted for 3.1.3.1b mixed forests with a continuous canopy and local occurrence of wood harvesting (0.292), 3.1.2.1b coniferous forests with a continuous canopy and local occurrence of wood harvesting (0.2816) and 3.1.1.4 plantations of broad-leaved trees (0.1392). The positive impact of watercourse that have preserved their natural shape and have not crossed artificial surfaces and agricultural areas was 0.05 . The high ratio of ecological barriers was also important $(0.10)$. Detailed analysis of the secondary landscape structure based on delineated land cover classes on the 5th hierarchical level caused a decrease of IELS. The lower value can be considered as an ability to better know the real state of the landscape structure, which is reflected in its ecological stability. The used grid method confirmed the hypotheses about the high ecological stability in squares with the occurrence of two or more land cover classes (pastures, dispersed natural woody vegetation in grass stands, forests, young forest, rare grass-herbaceous vegetation or shrub vegetation on rocks and wetlands) representing transitional zones between adjacent ecosystems (ecotones) that are characterized by a potentially increased diversity. 
